\title{
Reading and proclaiming the Advent call of John the Baptist: An empirical enquiry employing the SIFT method
}

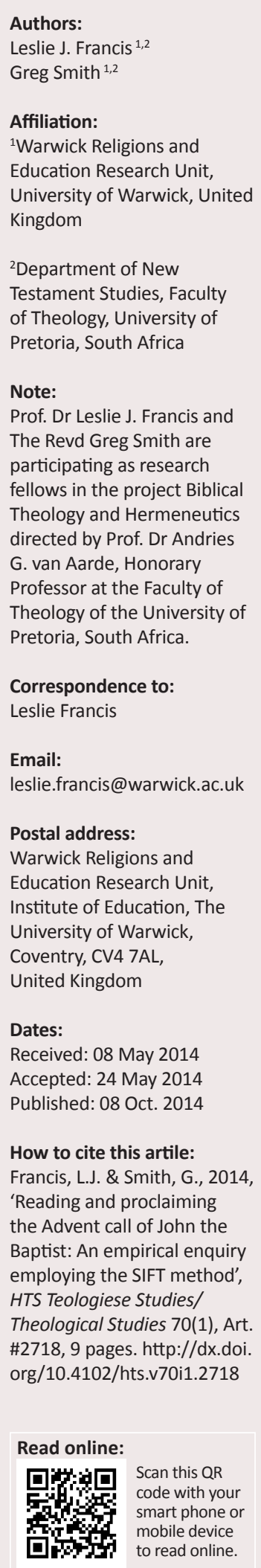

Drawing on Jungian psychological type theory, the SIFT method of biblical hermeneutics and liturgical preaching suggests that the reading and proclaiming of scripture reflects the psychological type preferences of the reader and preacher. This thesis is examined among a sample of clergy (training incumbents and curates) serving in the one Diocese of the Church of England $(N=22)$. After completing the Myers-Briggs Type Indicator, the clergy worked in groups (designed to cluster individuals who shared similar psychological type characteristics) to reflect on and to discuss the Advent call of John the Baptist. The Marcan account was chosen for the exercise exploring the perceiving functions (sensing and intuition) in light of its rich narrative. The Lucan account was chosen for the exercise exploring the judging functions (thinking and feeling) in light of the challenges offered by the passage. In accordance with the theory, the data confirmed characteristic differences between the approaches of sensing types and intuitive types, and between the approaches of thinking types and feeling types.

\section{Introduction}

Psychological type theory, as pioneered by Jung (1971) and as developed by the Myers-Briggs Type Indicator (Myers \& McCaulley 1985) has been drawn into conversation with practical, pastoral and empirical theology in a variety of ways. The theory of psychological type has been employed to illuminate differences in approaches to ministry (Oswald \& Kroeger 1988) and prayer styles (Michael \& Norrisey 1984; Duncan 1993). Empirical studies using measures of psychological type have been employed to profile church congregations (Francis, Robbins \& Craig 2011), clergy (Francis et al. 2007), and bishops (Francis, Whinney \& Robbins 2013). Within this context, a particularly fruitful contribution has been made by psychological type theory to the fields of biblical hermeneutics and preaching.

\section{Psychological type theory}

Psychological type theory identifies two distinct psychological processes, one described as the perceiving process, and the other described as the judging or evaluating process. The perceiving process is styled the irrational process since it is concerned with the ways in which information is gathered; the perceiving process does not make judgement about that data. The judging or evaluating process is styled the rational process since it is concerned with the ways in which information is evaluated. The perceiving process operates through two different functions: the sensing function (S) which is concerned with 'the detail' and the intuitive function $(\mathrm{N})$ which is concerned with 'the big picture'. The judging or evaluating process also operates through two different functions: the feeling function $(\mathrm{F})$ which is concerned with 'subjective values' and the thinking function $(\mathrm{T})$ which is concerned with 'objective logic'. According to the theory most people are able to access all four functions, but naturally develop one perceiving function over the other (sensing or intuition) and naturally develop one judging or evaluating function over the other (thinking or feeling). The analogy is with human handedness where most people develop their skills with one hand, to the comparative neglect of the other (cf. Francis \& Smith 2013).

In the account of type dynamics, psychological type theory takes the notion of the differential development of the four psychological functions (sensing, intuition, thinking and feeling) one step further. Not only do individuals tend to prefer one perceiving function over the other, and one judging function over the other, but they also tend to develop more strongly either their preferred perceiving function (sensing or intuition) or their preferred judging function (thinking or feeling) over the other. In this account of type dynamics one function becomes visible as the 
individual's dominant function, where this function shapes the dominant perspective on life. Thus, dominant sensing shapes the practical person, dominant intuition shapes the creative and imaginative person, dominant thinking shapes the strategic and logical person, and dominant feeling shapes the caring and humane person (cf. Francis \& Smith 2013).

Psychological type theory has been operationalised by a number of type indicators, type scales, or temperament sorters, including the Keirsey Temperament Sorter (Keirsey \& Bates 1978), the Myers-Briggs Type Indicator (Myers \& McCaulley 1985), and the Francis Psychological Type Scales (Francis 2005). In addition to distinguishing between two perceiving functions (sensing or intuition) and two judging functions (feeling or thinking), these measures also distinguish between two orientations (introversion or extraversion) and two attitudes towards the outer world (judging or perceiving) (cf. Francis \& Smith 2013).

The two orientations are concerned with the source of personal energy and where it is focused. Extraverts are oriented towards the outer world, where they are energised by people and events around them; they thrive in a stimulating and exciting environment and enjoy communicating. Introverts are energised by their inner world of ideas and concepts; they enjoy silence, solitude, and contemplation. The two attitudes towards the outer world are concerned with which of the two processes (judging or perceiving) is preferred in dealing with the outer world. Judging types deploy thinking or feeling in the outer world. They seek to rationalise, order, and structure their outer world. Perceiving types deploy sensing or intuition in the outer world. They have a flexible, open-ended, spontaneous approach to their outer world (cf. Francis 2010).

\section{Psychological type theory and preaching}

The connection between psychological type theory and preaching was raised insightfully by Stiefel (1992) in an essay entitled 'Preaching to all the people: The use of Jungian typology and the Myers-Briggs Type Indicator in the teaching of preaching and in the preparation of sermons.' Exploring this connection, Stiefel makes two main points. The first point is that the psychological type profile of the preacher may influence both the style in which the sermon is delivered and the content of the sermon. The second point is that the psychological type profile of the individual members of the congregation may influence their perception both of the style of the preacher's delivery and the content of the preacher's material. Stiefel illustrates these points by discussing the four components of psychological type theory in turn.

The distinction between introversion and extraversion may shape the style of preaching. Extravert preachers feel actively engaged with the congregation, with a generous use of gesture and a concern for eye contact. Extravert preachers often do well without a written text and develop ideas as they deliver them. Extravert preachers are likely to encourage some kind of interaction from the congregation and need some kind of response to feed them new energy to continue. Introvert preachers use gestures minimally or calculatedly and avoid eye contact unless specifically intending it. Introvert preachers generally have written texts or have gone to great trouble to practise preaching without a text. Introvert preachers expect the congregation to reflect on what is said and are uncomfortable when unexpected feedback takes place. For introverts feedback drains energy rather than generates energy. Stiefel suggests that introvert congregants may feel more comfortable with introvert preachers and that extravert congregants may feel more comfortable with extravert preachers.

The distinction between sensing and intuition begins to shape the content of preaching. Preachers who prefer sensing may concentrate on the details of the scripture passage and fail to engage intuitive types in the congregation. Preachers who prefer intuition may concentrate on the big themes and ideas raised by the scripture passage and fail to keep the attention of sensing types in the congregation.

The distinction between thinking and feeling also shapes the content of preaching. Preachers who prefer thinking are likely to focus on theological concepts and to present them with well-ordered clarity, but fail to engage the hearts of feeling types in the congregation. Preachers who prefer feeling are likely to focus on God's relationship with humankind and to emphasise the fellowship and warmth of the Christian community, but fail to engage the minds of thinking types in the congregation.

The distinction between judging and perceiving may shape the way in which preachers prepare their sermon, and as a consequence the immediacy with which their ideas emerge in the pulpit. Preachers who prefer judging are likely to prepare sermons days, weeks, or even months in advance. Such preachers are also well placed to organise the rest of the service well in advance and to coordinate readers, musicians and worship leaders. Preachers who prefer perceiving are likely not to find the inspiration they need for preaching until the last minute. Such preachers may find it difficult to line up the rest of the service well in advance. It is this fundamental difference between preferences for judging and preferences for perceiving that may cause deep tensions within ministry teams.

\section{Psychological type theory and biblical hermeneutics}

The connection between psychological type theory and biblical hermeneutics has been raised insightfully in a series of studies by King (2010, 2012, in press) where he introduces the notion of personality-critical analysis to biblical scholarship. Exploring this connection King makes two points. The first point is that key aspects of authors' personality are likely to be reflected in the language, themes and emphases of their writing. The second point is that this insight might hold a 
fresh key for unravelling a complex issue in biblical studies, namely that of distinguishing between multiple authorship, either within a single document or within a designated corpus of writings attributed to a single author. King (2012:864) sets out his analytic framework by suggesting that personalitycritical analysis looks for the following characteristics:

- Introversion: reflection, quiet, depth, prefers writing

- Extraversion: action, busy, noise, socialising, prefers speaking

- Sensing: simplicity, conciseness, storytelling, facts, details, practicality, senses

- Intuition: images, metaphors, ideas, patterns, hunches, future, the big picture

- Feeling: values, harmony, persuasion, relationships, sympathy

- Thinking: logic, objectivity, fairness, justice

- Perceiving: flexibility, discovery, adaptability, variety

- Judging: planning, closure, deadlines, control, structure. (p. 864)

In his first study on personality-critical analysis, King (2010) revisited the classic problem of distinguishing between the author of the Johannine letters and the author of the Fourth Gospel. In his analysis of the first of the Johannine letters, King identifies 98 instances of sensing characteristics, with 37 additional instances of the combined sensing-judging temperament, against a remarkable absence of intuitive characteristics. He identified 49 instances of feeling characteristics, compared with only two instances of thinking characteristics. Analysis of the second and third Johannine letters confirmed the identification of an author who preferred sensing and feeling. This profile of the author of the Johannine letters stands in strong contrast with Duncan's (1993:68-69) characterisation of the author of the Fourth Gospel as a strong intuitive type. In the Fourth Gospel, many of the words carry layers of meaning: 'Conceptual words are prominent: glory, truth, knowledge, regeneration, belief, word, life, light, love. There are [few] signs of the clarity and conciseness of a sensing writer' (King 2010:83), and the direct narratives of straightforward events and down-to-earth parables are largely absent. Instead there are long complex discourses, discourses designed to fire the imagination of intuitive readers. The miracles are replaced by signs and the signs are fully explored. The Fourth Gospel is powered by imaginative symbols that would frustrate the sensing readers' quest for directness: I am the bread of life, the light of the world, the door, the good shepherd, the way and the truth and the life, and the true vine (cf. King 2010:83).

In his second study in personality-critical analysis, King (2012) revisited the classic problem of distinguishing between the multiple authors of the Pauline corpus. First King applied personality-critical analysis to the seven Pauline letters which he argues are generally accepted as genuine (1 Th; Phlp; Phlm; Gl; 1 Cor; 2 Cor; Rm). His data suggests that these letters all show considerable uniformity pointing to an ESTJ author. This personality profile, King argues, explains Paul's extraordinary zeal in evangelism, his logical teaching and his need to assert his status as an Apostle. His need for control caused him to agonise over deviations in the churches and to set offenders right. His Achilles heel is seen as Paul's attitude to criticism: he writes rudely and answers with venom. Secondly, King's analysis of Colossians and Ephesians points to a common author (Deutero-Paul), an INFP, who, while completely opposite to Proto-Paul (ESTJ), was ideally competent to promote Paul's teaching in a more colourful and persuasive style. King's analysis of 2 Thessalonians points to a third author, another ESTJ, but one with a more authoritative style than ProtoPaul. Finally, King's analysis of the pastoral letters points to a common author (Tetarto-Paul), an ISTJ, who, according to King, is extreme enough in SJ temperament to be classed as a control freak.

In his third study in personality-critical analysis, King (in press) returns to exploring the psychological type profile of the Fourth Evangelist and presents him as INFJ.

\section{The SIFT approach}

Working independently with psychological type theory, Francis (1997) first introduced the sensing, intuition, feeling, thinking (SIFT) approach to biblical hermeneutics and liturgical preaching. The theory underlying this approach was further developed and elaborated by Francis (2003) and by Francis and Village (2008). The theory has been exemplified in practice by a series of three books that provide model sermons based on the principal Gospel reading proposed for each Sunday by the Revised Common Lectionary. Each model sermon addresses the Gospel passage in sequence from the perspectives of sensing, intuition, feeling, and thinking (Francis \& Atkins 2000, 2001, 2002).

The theory underpinning the SIFT approach differs from Stiefel's (1992) approach in two important ways. Firstly, Stiefel appropriated psychological type theory for preaching as a psychological insight helpful to understand the process of preaching. Here is a psychological tool that aids preaching. The SIFT approach repositions psychological type theory as a theological insight into the nature of human beings created in the image of God. The notion of the theology of individual differences within which this insight is grounded is rooted in a strong doctrine of creation rooted in a distinctive reading of Genesis 1:27. By proposing that both male and female are created in the image of God, Genesis 1:27 suggests that the divine image embraces diversity and that God intended such diversity to be reflected in human beings. The theology of individual differences fully appreciates the implications of the way in which the divine image is marred by the fall, and tries to distinguish between the individual differences observed in human beings who may reflect the image of God and those who may reflect the fall. Sex differences reflect the image of God and by extension so may other differences like fundamental ethnic differences and fundamental psychological differences like extraversion and introversion, sensing and intuition, thinking and feeling, judging and perceiving. 
Secondly, Stiefel appropriated psychological type theory for preaching as a tool concerned with communication theory. The SIFT approach repositions psychological type theory as hermeneutical theory. Just as hermeneutical theory has embraced sociological insights to recognise the validity of different interpretations of scripture by men and by women, so the SIFT approach has embraced psychological insights to recognise the validity of different interpretations of scripture by sensing types, by intuitive types, by feeling types and by thinking types. According to this approach, full access to the revelation of God through scripture needs the insights of men and women to be shared and equally needs the insights of sensing types, intuitive types, feeling types and thinking types to be shared.

The SIFT approach recognises that it is the two core processes of psychological type theory that are engaged in the hermeneutical activity. The two perceiving functions (sensing and intuition) and the two judging functions (feeling and thinking) lead to distinctive interpretations. The two orientations (extraversion and introversion) and the two attitudes (judging and perceiving) define the context and the manner in which the hermeneutical functions operate.

In a systematic way the SIFT method of biblical hermeneutics and liturgical preaching addresses to a passage of scripture the four sets of questions posed by the two perceiving functions of sensing and intuition and the two judging functions of thinking and feeling. Sensing and intuition are applied first, as the perceiving functions are concerned with gathering information and ideas. These are the irrational functions unconcerned with making judgements or with formulating evaluations. Thinking and feeling are applied second, as the judging functions are concerned with evaluating information and ideas. These are rational functions.

In the SIFT method the first step addresses the sensing perspective. It is this perspective that focuses on the passage of scripture itself, giving attention to the details of a passage, and possibly drawing on the insights of the historical methods of biblical scholarship. The sensing questions ask: 'How does this passage speak to the sensing function? What are the facts and details? What is there to see, to hear, to touch, to smell, and to taste?'

The second step addresses the intuitive perspective. It is this perspective that relates a passage of scripture to wider issues and concerns. The intuitive questions ask: 'How does this passage speak to the intuitive function? What is there to speak to the imagination, to forge links with current situations, to illuminate issues in our lives?'

The third step addresses the feeling perspective. It is this perspective that examines the human interest in the passage of scripture and learns the lessons of God for compassionate and harmonious living. The feeling questions ask: 'How does this passage speak to the feeling function? What is there to speak about the relationships between people, about fundamental human values, and about what it is to be truly human?'

The fourth step addresses the thinking perspective. It is this perspective that examines the theological interest in the passage of scripture and that reflects critically and rationally on issues of principle. The thinking questions ask: 'How does this passage speak to the thinking function? What is there to speak to the mind, to challenge us on issues of justice and truth, and to provoke profound theological thinking?' (for the four sets cf. Francis 2010).

\section{Interpreting and proclaiming scripture}

A series of recent empirical studies, employing qualitative research techniques has set out to test the theory underpinning the SIFT approach to biblical hermeneutics and liturgical preaching by observing the connection between psychological type preferences and the ways in which clergy and lay people interpret and proclaim scripture (Francis 2010, 2012a, 2012b, 2013; Francis \& Jones 2011, 2014; Francis \& Smith 2012, 2013). Each of these studies has focused on specific passages of scripture and invited participants to work together in groups that have drawn together individuals of similar psychological type preferences. On some occasions, the participants have been invited to work in four parallel groups according to dominant psychological type preferences. On some occasions the participants have first been invited to share in groups established by the perceiving process (distinguishing between sensing and intuition) and then in groups established by the judging process (distinguishing between thinking and feeling). In the latter case the tasks have been differentiated so that the groups based on sensing and intuition have been invited to work on an issue drawing on the perceiving functions and so that the groups based on thinking and feeling have been invited to work on an issue drawing on the judging functions.

In the first study, Francis (2010) invited two groups of Anglican preachers (24 readers in England and 22 clergy in Northern Ireland) to work in groups defined by their dominant psychological type preferences (dominant sensing types, dominant intuitive types, dominant thinking types and dominant feeling types). Within these dominant type groups they were asked to prepare a presentation on Mark 6:34-44 (the feeding of the five thousand).

In the second study, Francis and Jones (2011) explored Mark 16:1-8 and Matthew 28:1-15 (resurrection narratives), working with two groups (26 ministry training candidates, and 21 Anglican clergy and readers), and employing a twostage process. Firstly, the participants were divided according to the perceiving process (sensing and intuition) and invited to discuss the Marcan narrative. Secondly, the participants were divided according to the judging process (thinking and feeling) and invited to discuss the Matthean narrative. 
In the third study, Francis (2012b) explored Mark 11:11-21 (the cleansing of the temple and the incident of the fig tree), working with three groups (31 Anglican clergy, 14 clergy and lay preachers and 47 lay people and clergy). The participants were invited to discuss the passage in two stages. Firstly, the participants were divided according to the perceiving process, distinguishing between groups of sensing types and groups of intuitive types. Secondly, the participants were divided according to the judging or evaluating process, distinguishing between groups of feeling types and groups of thinking types.

In the fourth study, Francis (2012a) explored John 6:4-22 (the Johannine feeding narrative), working with two groups of ministry training candidates (13 women and 6 men, and 2 women and 5 men). On this occasion Francis invited the participants to discuss the passage in two stages. Firstly, the participants were divided according to the perceiving process and asked to accomplish three tasks: to reflect on the passage, to note issues of interest to them, and to prepare material for preaching. Secondly, the participants were divided according to the judging process and asked to accomplish three tasks: to reflect on the passage, to note the issues raised by the passage, and to prepare material for preaching (for the four studies cf. Francis 2010).

In the fifth study, Francis and Smith (2012) explored Matthew 25:31-46 (separating sheep from goats), working with a group of 25 Anglican clergy (11 women and 14 men). On this occasion the participants were assigned to four groups (based on dominant type preferences) but they were not told the basis on which the groups had been selected. The groups were asked to discuss and to document how they would preach on the passage.

In the sixth study, Francis and Jones (2014) explored John 6:5-15 (the Johannine feeding narrative), working with a group of 13 newly ordained Anglican priests who were invited to reflect on the Eucharistic imagery of the passage. Firstly, the participants were divided into two groups according to the perceiving process ( 7 sensing types and 6 intuitive types). Given only the first part of the narrative (Jn 6:5-11), they were asked to discuss what the passage had to say about life in the Eucharistic community. Secondly, the participants were divided into three groups according to the judging process (4 thinking types, 5 high scoring feeling types and 4 low-scoring feeling types). Given now the complete narrative (Jn 6:5-15), they were asked to discuss the issues about life in the Eucharistic community raised by the extra verses.

In the seventh study, Francis and Smith (2013) explored Matthew 2:13-20 and Luke 2:8-16 (birth narratives), working with a group of 12 training incumbents and 11 recently ordained curates ( 8 women and 15 men). Firstly, the narrative of the shepherds from Luke was discussed by three groups organised according to scores on the perceiving process. Secondly, the narrative of the massacre of the infants from
Matthew was discussed by three groups organised according to scores on the judging process (cf. Francis \& Smith 2013).

A clear consensus has begun to emerge from the cumulative evidence generated by these seven studies, supporting the view that psychological type preferences are linked with distinctive approaches to reading and to proclaiming scripture. In accordance with the theory, sensing types tend to focus on details in the passage, but find it hard to identify the larger themes. Intuitive types tend to identify imaginative themes, but show less interest in the details. Thinking types tend to identify and to analyse the big theological issues raised by the passage. Feeling types tend to give greater emphasis to matters of the human heart illustrated by the passage. As this body of research develops and grows it has been possible to test the theory over a wider range of material, but as yet the empirical bases for the theory remain relatively restricted and further studies are needed. The present paper has been designed to do that, but also to build on an eighth study reported by Francis (2013).

Francis (2013) took a somewhat different approach from the earlier studies. Instead of working with professional people, trained in the study of scripture and in preaching, Francis (2013) worked with a small group of 8 people (3 women and 5 men) whom Astley (2002) would style as 'ordinary theologians':

$[P]$ eople associated with their local church and attending a church-based study group. In this activity, Francis (2013) focused on Mark 1:2-8 and Luke 3:2b-20 (John the Baptist). First, the Marcan narrative (concentrating on the imagery of John the Baptist) was discussed by two groups organised according to scores on the perceiving process (4 sensing types and 4 intuitive types). The data confirmed the propensity for ordinary readers who preferred sensing to concentrate on the details and practical realities of the narrative, and for those who preferred intuition to focus on the bigger picture. Second, the Lucan narrative (concentrating on the teaching of John the Baptist), was discussed by two groups organised according to scores on the judging process ( 3 thinking types and 5 feeling types). The data confirmed the propensity for ordinary readers who preferred feeling to identify with the human concerns displayed in the narrative, and for those who preferred thinking to analyse the narrative and to identify the theological issues. (Francis \& Smith 2013:4)

\section{Research question}

The study reported by Francis (2013) demonstrated that the two distinctive accounts of John the Baptist presented in Mark 1 and Luke 3 were well-chosen passages to draw out, respectively, the contrasting perspectives of sensing and intuition and the contrasting perspectives of thinking and feeling. However, while the sample selected by Francis (2013) was able to link these passages of scripture with the psychological type profile of ordinary theologians, the study left open for future research to explore how professional theologians may handle this material. The aim of the present study, therefore, is to address this question by inviting two groups of Anglican clergy to discuss and to reflect 
on the Advent call of John the Baptist as presented within Mark 1:2-8 (distinguishing between sensing and intuition) and as presented within Luke 3:7-17 (distinguishing between feeling and thinking). The hypothesis was that clergy who are largely naive about the SIFT method, when placed in groups of individuals sharing the same psychological type preferences, will generate interpretations of (or reflections on) scripture broadly consistent with their personal psychological type style (cf. Francis \& Smith 2013).

\section{Method \\ Procedure}

In the context of a residential programme held just before the beginning of Advent (during late November 2013), the participants were invited to complete a recognised measure of psychological type and to experience working in groups structured on the basis of psychological type theory. Reading, reflecting on and proclaiming scripture was an integral part of the group experience (cf. Francis \& Smith 2013).

\section{Measure}

Psychological type was assessed by the 126-item Form G (Anglicised) of the Myers-Briggs Type Indicator (Myers \& McCaulley 1985). This instrument uses a force-choice questionnaire format to indicate preferences between the two orientations (extraversion or introversion), the two perceiving functions (sensing or intuition), the two judging functions (feeling or thinking), and the two attitudes (judging or perceiving). Broad support for the reliability and validity of the instrument is provided in a study among 863 Anglican clergy, by Francis, Craig, Whinney, Tilley and Slater (2007) who reported the following alpha coefficients: extraversion, .80; introversion, .79; sensing, .87; intuition, .82; thinking, .79; feeling, .72; judging, .85; perceiving, .86 (cf. Francis \& Smith 1013).

\section{Participants}

The programme was attended by nine sets of training incumbents and their curates, together with three curates unaccompanied by their training incumbent and one incumbent unaccompanied by his curate. The group of 22 participants comprises 5 women and 17 men. Profiles provided by the Myers-Briggs Type Indicator identified preferences for introversion (15) over extraversion (7), preference for intuition (13) over sensing (9), preference for feeling (12) over thinking (10), and preference for judging (13) over perceiving (9). Of the 16 complete types, the most frequently represented types were ISTJ (4), INFJ (3), INFP (3) and ENFP (3).

\section{Analysis}

The groups were structured on the basis of psychological type theory and assigned specific tasks. They were invited to work on these tasks and to agree on a common presentation of their conclusions. These presentations were both written in text form and spoken in plenary when the groups came together to share their conclusions. The written texts and the spoken presentations (which were carefully noted by the authors) provide the data for analysis (cf. Francis \& Smith 2013).

\section{Results}

\section{Perceiving process Procedure}

The participants were divided into three groups: seven participants who recorded highest preference scores on sensing $(33,31,23,23,21,17,15)$, seven participants who recorded highest preference scores on intuition $(45,43,41,31$, $27,25,19)$, and five participants who recorded lower scores on intuition, together with three participants who recorded lower scores on sensing. The participants were invited to read Mark 1:2-8 and then reflect on the following questions: Here is Mark's narrative about John the Baptist. What do you see in this passage and what possibilities does it raise for the church this Advent? The following analysis concentrates on the two groups that contained the highest preference scores on sensing and the highest preference scores on intuition.

\section{Findings}

The group of high scoring sensing types was quite slow to get started. The first issue raised was that this passage from Mark was the wrong choice, since the lectionary readings for this Advent were from Matthew. The second issue raised concerned the mechanism for feeding back. This issue was resolved by asking the person who had raised it to deal with it. With the preliminary matters over, the discussion of the passage began.

The first voice saw in the passage a very real sense of expectation and a very real sense of preparation. John the Baptist was full of expectancy for the coming of Christ. The passage from Isaiah shows that God had prepared all this long ago. God had even prepared to send the messenger ahead of the Messiah.

The second voice saw the need to explain the background to the passage. In the context of God's covenant, the prophets were God's enforcers who came with a message of encouragement and judgement. John the Baptist came as the last prophet of the Old Testament, offering encouragement and judgement.

The third voice saw the people being prepared to get involved in the story. All the people went down to be baptised.

The second voice re-engaged and suggested that the people had read the signs correctly. They had seen John appear in the guise of Elijah. The message for today's church is that we have to keep our eyes open for the signs God is offering to us.

The fourth voice noted that our whole country is expectant for the secular Christmas but is not tuned-in to the message of John, as the people of Judea and Jerusalem had been tuned- 
in to the message of John. This led to wider discussion and reflection of how people today can come to recognise their need of Jesus. Human nature has not changed and we must educate people to recognise their need of God.

Coming back to the text, a new voice noted that at the time of John the Baptist the people had been prepared by God through the invasion of the Roman occupying forces. Perhaps something like that is needed today to wake people up to what really matters. As an indication that people today may be waking up to a greater sense of moral responsibility, attention was drawn to an article in the current edition of Church Times relating how a church-led campaign had prompted a major retailer to remove potentially provocative posters from bus shelters.

The session then ended as it had begun by asking why the groups had been invited to study the narrative from Mark rather than from Matthew. Perhaps the course leader just uses the same passages every year?

The group of high scoring intuitive types immediately found themselves looking ahead to the sermon they might preach. This was followed by an identification of the rich language and the vivid symbolism.

Wide-ranging ideas included the reclaiming of the wilderness as a place where God may be encountered; John the Baptist as an embodiment of his message; a new crossing into the Promised Land and the church as messengers. The idea that had the most traction for the group was the wilderness as a place on the margins or edge of society. What had persuaded people to leave the city in droves, someone wondered? The city was identified as the home of conventional religion; with the recognition that it was outside the city that something new might be found.

Without any prompting from the text, the group mused on the attitude of those on the edge of the crowd, those perhaps not engaged by the Baptist's message. This was considered analogous with the crowds entering church in Advent, perhaps an example of eisegesis? Advent, indeed, was uppermost in the mind of the group, one contributor enquiring what theme should be picked up for the season - a typically intuitive approach to the task of preaching.

Ideas and images continued to pour forth in a great stream of animated creative energy: the culmination of the Baptist's story - his head on a plate; the parable of the indignant response to the irresponsible dog owners; the importance of embodying a different way of living; and the erosion of the church as an institution. For every fresh idea, there was a new question, for example how do we proclaim in our current situation a baptism of repentance and the forgiveness of sins?

This group of high scoring intuitive types was evidently energised by spending time together. Their concern was for the grand themes of Advent and John the Baptist's ministry, resisting altogether any temptation to approach the text in sequential order, note particular words or phrases, or construct a coherent narrative.

\section{Judging process Procedure}

The participants were divided into three groups: seven participants who recorded highest preferences on thinking $(45,41,35,27$ 19, 17, 17); eight participants who recorded highest preferences on feeling $(35,35,31,29,25,23,23$, 21 ), and four participants who recorded lower scores on feeling, together with three participants who recorded lower scores on thinking. The participants were invited to read Luke 3:7-17 and to reflect on the following questions: Here is Luke's narrative about John the Baptist. What issues does this passage raise about the nature and activity of God? The following analysis concentrates on the two groups that contained the highest preference scores on thinking and the highest preference scores on feeling (cf. Francis \& Smith 2013).

\section{Findings}

The group of high scoring feeling types began by discussing by whom and in what way the feedback would be given. Some wanted to use a flip chart and some did not. No one was eager to volunteer to present the feedback. In order to maintain harmony the group glossed over these difficulties and proceeded without planning how feedback would be given.

The main issue raised by this group concerned the uncomfortable side of John the Baptist's message, including reference to the wrath to come, the axe, the fire, the winnowing fork. Such passages can be used to provide teaching about hell fire and to promote oppression, like anti-Semitism. Such passages are inconsistent with the overriding Gospel message concerning the love of God. Various strategies were employed to address this problem.

One voice read the passage as being full of hope. The message was that everyone could escape the wrath of God by following the invitation of John the Baptist. The wrath of God was not a threat, but a clear implication of making the wrong choices.

A second voice took a different strategy saying that the job of the preacher was to read texts like this against knowing the full story of the Gospel. John the Baptist's teaching is not consistent with the overriding teaching of Jesus. It is appropriate for the preacher to draw out the teaching about generosity given to the tax collectors and to the soldiers, and then to discard the rest.

A third voice suggested that the passage should be read in the context of John the Baptist trying to command the attention of the crowd. Language about the brood of vipers and about the unquenchable fire was merely a rhetorical device for effect and not to be taken literally. 
A fourth voice went back to the text and offered a different reading according to which the wrath to come referred not to the wrath of God but to the occupying Roman forces and the unquenchable fire referred not to the fires of hell but to the refining and cleansing fire of the Holy Spirit that would burn the chaff of sin and fit people for the coming of Christ.

A fifth voice offered the view that just because there is stuff in the Bible about God; it does not necessarily mean that God is really like that. We must differentiate between what the people who wrote the Bible think about God and the real nature of God.

By this stage the passage began to seem much less challenging. Then, however, a different conversation emerged concerning how people today may feel about the message to give away the second coat or to share the food. For many middle-class people, this teaching would be very uncomfortable and very hard. The conversation moved on to consider the involvement of churches in the process of food banks, the plight of individuals dependent on food banks, and the incredible sense of inequality in today's society that generates this plight.

Further reflection on the forgiving nature of God led to consideration of the Lucan parable of the two sons. The father welcomed the return of the younger son with open arms and with the fatted calf. The father longed for the older son to join the party too, but the older son excluded himself. God wants none to be excluded.

The group of high scoring thinking types quickly embraced judgement as the key theme of the passage, opining in one case that the country is in a mess for lack of a sense of pending judgement. The group displayed no discomfort with this concept nor indeed the connected idea of God's wrath. However, there was recognition that logical arguments should be mustered, with appeals drawn from the text to fairness and consistency in that the standard being applied was the same for all parties, both insiders and outsiders.

One voice expressed a desire to challenge the contemporary assumption that everyone goes to Heaven, while another voice produced the epithet, 'those who think they're in are out and those who think they're excluded are in.' One facet of judgement, they considered, was the reconstitution of Israel, and the decision as to who will be part of God's family.

The question arose whether verse 17 represented a misunderstanding of God? However, the resounding answer from several voices in this group of high scoring thinking types was 'no'. Jesus talks about hell, they noted, more than any other person in the Bible. His language is consistent with that of the Old Testament prophets, compared with 'white washed tombs'. The God of the Old Testament, they insisted, was not different from the God of the New Testament.

There was a passing reference to God's love, noting that behaviour does not diminish God's love for his people, but behaviour does matter and repentance is of great importance. The group betrayed an underlying concern to justify its argument, perhaps unconsciously recognising that its views were not universally accepted in the church. Both Cramner and Barth were referenced in an attempt to underline the consistency of their argument.

The final summary was encapsulated by a group statement to the effect: God is active in surprising and challenging ways, and demands action from his people (both the children of Abraham and Gentiles).

\section{Conclusion}

This study set out to expand the empirical investigation of the theory underpinning the SIFT approach to biblical hermeneutics and liturgical preaching. It did so by working with a group of clergy (training incumbents and curates) within the context of a residential programme held during late November immediately before the beginning of Advent. The research method invited these clergy to work in typealike groups to explore the Advent call of John the Baptist. In type-alike groups structured according to preferences within the perceiving process (sensing and intuition) the clergy were invited to read and to reflect on Mark 1:2-8, addressing the question: 'What do you see in this passage and what possibilities does it raise for the church this Advent?' In type-alike groups structured according to preferences within the evaluating or judging process (thinking and feeling), the clergy were invited to read and to reflect on Luke 3:7-17, addressing the question: 'What issues does this passage raise about the nature and activity of God?' The two questions were deliberately chosen to bring respectively the perceiving functions and the judging functions to the fore in discussion. Three main conclusions emerge from the data generated by the different groups in response to these two questions and the two specified passages of scripture.

The first conclusion concerns the ways in which individuals read, reflect on and interpret scripture, reflecting their own personal psychological preferences. Feeling types really do give priority to the personal and interpersonal implications, and thinking types really do go for an analysis of the issues raised. Sensing types really do worry about the detail of the practice of scriptural interpretation, while intuitive types really do search for overarching grand themes to the neglect of the detail of an exercise. A reader perspective on biblical hermeneutics is incomplete therefore if the contribution of psychological type theory is not taken into account (cf. Francis \& Smith 2013).

The second conclusion concerns the way in which psychological preferences not only affect a reader's approach to the text, but also influence the very way in which theology is undertaken. One group (high scoring feeling types) reading the Lucan passage reference Jesus as offering very different teaching, even contradictory teaching, to that of John the Baptist; while a different group (high scoring thinking types) also reference Jesus, but as the one who speaks of hell more 
than any other New Testament figure. The preference for a 'soft' theology of judgement, with its emphasis on mercy, might be expected of feeling types, while a preference for 'firm' judgement, with its emphasis on justice, might be expected of thinking types. Both groups skilfully utilise hermeneutical tools to ensure the text is interpreted in accordance with their preference in the judging process.

The third conclusion is that when groups are fashioned according to similar preferences in the perceiving or judging process, an energising harmony is created within the group. Individuals are able to express their views with confidence, safe in the knowledge that they are in the company of the like-minded. A safe space is created for views to be expressed that might be seen as controversial in other settings. This allows depth in the hermeneutical process, but perhaps lacks breadth.

\section{Acknowledgements Competing interests}

The authors declare that they have no financial or personal relationship(s) that may have inappropriately influenced them in writing this article.

\section{Authors' contributions}

The authors L.J.F. (University of Warwick) and G.S. (University of Warwick) shared equally in the process of generating and analysing the original empirical data employed in this study. L.J.F., as first author, took the lead in developing the theoretical framework within which these data are set.

\section{References}

Astley, J., 2002, Ordinary theology: Looking listening and learning theology, Ashgate, Aldershot.

Duncan, B., 1993, Pray your way: Your personality and God, Darton, Longman \& Todd, London.

Francis, L.J., 1997, Personality type and scripture: Exploring Mark's Gospel, Mowbray, London.

Francis, L.J., 2003, 'Psychological type and biblical hermeneutics: SIFT method of preaching', Rural Theology 1, 13-23.

Francis, L.J., 2005, Faith and psychology: Personality, religion and the individual, Darton, Longman \& Todd, London.

Francis, L.J., 2010, 'Five loaves and two fishes: An empirical study in psychological type and biblical hermeneutics among Anglican preachers', HTS Teologiese Studies/ Theological Studies 66(1), 5 pages. http://dx.doi.org/10.4102/hts.v66i1.811
Francis, L.J., 2012a, 'Interpreting and responding to the Johannine feeding narrative: An empirical study in the SIFT hermeneutical method among Anglican ministry training candidates', HTS Teologiese Studies/Theological Studies 68(1), 9 pages. http://dx.doi.org/10.4102/hts.v68i1.1205

Francis, L.J., 2012b, 'What happened to the fig tree? An empirical study in psychological type and biblical hermeneutics', Mental Health, Religion and Culture 15, 873-891. http://dx.doi.org/10.1080/13674676.2012.676252

Francis, L.J., 2013, 'Ordinary readers and reader perspective on sacred texts: Drawing on empirical theology and Jungian psychology', in J. Astley \& L.J. Francis (eds.), Exploring ordinary theology: Dimensions of everyday Christian existence and the life of the Church, pp. 87-96, Ashgate, Farnham.

Francis, L.J. \& Atkins, P., 2000, Exploring Luke's Gospel: A guide to the gospel readings in the Revised Common Lectionary, Mowbray, London.

Francis, L.J. \& Atkins, P., 2001, Exploring Matthew's Gospel: A guide to the gospel readings in the Revised Common Lectionary, Mowbray, London.

Francis, L.J. \& Atkins, P., 2002, Exploring Mark's Gospel: An aid for readers and preachers using year $B$ of the Revised Common Lectionary, Continuum, London.

Francis, L.J. \& Jones, S.H., 2011, 'Reading and proclaiming the resurrection: an empirical study in psychological type theory among trainee and experienced preachers employing Mark 16 and Matthew 28', Journal of Empirical Theology 24 1-18. http://dx.doi.org/10.1163/157092511X571141

Francis, L.J. \& Jones, S.H., 2014, 'Life in the eucharistic community: An empirical study in psychological type theory and biblical hermeneutics reading John 6:5-15, Pastoral Psychology 63, 281-290. http://dx.doi.org/10.1007/s11089-013-0540-x

Francis, L.J., Craig, C.L., Whinney, M., Tilley, D. \& Slater, P., 2007, 'Psychological profiling of Anglican clergy in England: Employing Jungian typology to interpret diversity, strengths, and potential weaknesses in ministry', International Journa of Practical Theology 11, 266-284. http://dx.doi.org/10.1515/IJPT.2007.17

Francis, L.J., Robbins, M. \& Craig, C.L., 2011, 'The psychological type profile of Anglican churchgoers in England: Compatible or incompatible with their clergy?' International Journal of Practical Theology 15, 243-259. http://dx.doi. org/10.1515/IJPT.2011.036

Francis, L.J. \& Smith, G., 2012, 'Separating sheep from goats: Using psychological type theory in a preaching workshop on Matthew 25:31-46', Journal of Adult Theological Education 9, 175-191.

Francis, L.J. \& Smith, G., 2013, 'Reading and proclaiming the Birth Narratives from Luke and Matthew: A study in empirical theology amongst curates and their training incumbents employing the SIFT method', HTS Teologiese Studies/Theological Studies 69(1), 13 pages. http://dx.doi.org/10.4102/hts.v69i1.2001

Francis, L.J. \& Village, A., 2008, Preaching with all our souls, Continuum, London.

Francis, L.J., Whinney, M. \& Robbins, M., 2013, 'Who is called to be a bishop?, A study in psychological type profiling of bishops in the Church of England', Journal of Beliefs and Values 34, 135-151. http://dx.doi.org/10.1080/13617672.2013.801647

Jung, C.G., 1971, Psychological types: The collected works, vol. 6, Routledge and Kegan Paul, London.

Keirsey, D. \& Bates, M., 1978, Please understand me, Prometheus Nemesis, Del Mar, CA.

King, D.E.N., 2010, 'The author of John's letters: The Evangelist, or another?' Journa of Beliefs and Values 31, 81-87. http://dx.doi.org/10.1080/13617671003666795

King, D.E.N., 2012, 'The four Pauls and their letters: A study in personality-critical analysis', Mental Health, Religion and Culture 15, 863-871. http://dx.doi.org/10. 1080/13674676.2012.677591

King, D.E.N., (in press), 'The personality of the Fourth Evangelist', Mental Health, Religion and Culture.

Michael, C.P. \& Norrisey, M.C., 1984, Prayer and temperament: Different prayer forms for different personality types, The Open Door, Charlottesville, VA.

Myers, I.B. \& McCaulley, M.H., 1985, Manual: A guide to the development and use of the Myers-Briggs Type Indicator, Consulting Psychologists Press, Palo Alto, CA.

Oswald, R.M. \& Kroeger, O., 1988, Personality type and religious leadership, The Alban Institute, Washington, DC.

Stiefel, R.E., 1992, 'Preaching to all the people: The use of Jungian typology and the Myers-Briggs Type Indicator in the teaching of preaching and in the preparation of sermons', Anglican Theological Review 72, 175-202. 